\title{
19. SYNTHETIC SEISMOGRAMS AT SITE 866: ORIGIN OF REFLECTIONS AND IMPLICATIONS FOR RECOGNIZING THE LIMESTONE/BASALT TRANSITION IN CRETACEOUS MID-PACIFIC GUYOTS ${ }^{1}$
}

\author{
Jeroen A.M Kenter ${ }^{2}$ and Jan Stafleu ${ }^{2}$
}

\begin{abstract}
Synthetic seismograms at Hole 866 were derived from sonic velocity and neutron density logs and compared to the lithology and seismic reflection data. In addition, logs of neutron density, neutron porosity, resistivity, gamma-ray, and discrete measurements were used to generate pseudo-velocity logs as input for synthetic seismograms to evaluate their potential as proxy for sonic velocity. The experiment has several implications for the study of seismic reflection profiles over Cretaceous Mid-Pacific guyots. High-amplitude reflections in the synthetic seismograms derived from log velocity and density are generated at lithologic boundaries, possibly related to changes in sea level or oceanographic events, at diagenetic boundaries (dolomitization), and by interference processes. The generally poor correlation between the synthetic seismogram and reflection seismic profile may be related to quality of recording, the quality of the well logs, rapid lateral changes in lithology or diagenetic overprinting, or changing interference patterns. The precise cause remains unclear, but the synthetic seismograms suggest that it is difficult to identify reflections in conventional seismic reflection profiles that are related to changes in sea level or oceanographic events and to correlate these to other guyots. In addition, as the impedance contrasts between limestone and basalt in these guyots is smaller, or equal to, the impedance contrasts within the limestone succession, it is nearly impossible to identify a basement reflection based on amplitudes alone.

Synthetic seismograms calculated from sonic velocity, neutron density, neutron porosity, and resistivity logs produce similar results. Gamma-ray data are poorly correlated to impedance because the clay-content is not the primary source of gamma-ray activity. Resistivity, however, is an unexpectedly good proxy for impedance. Density shows a useful correlation because Gardner's equation works well for pure limestone, whereas Wyllie's equation underestimates velocity.
\end{abstract}

\section{INTRODUCTION}

Numerous chains and clusters of Cretaceous seamounts, some of which are flat-topped guyots having summit-depths of about $1500 \mathrm{~m}$, are scattered on the western Pacific Ocean floor (Menard, 1964; Winterer, 1973; Matthews et al., 1974; Winterer and Metzler, 1984; McNutt and Fischer, 1987; ODP Leg 143 Shipboard Scientific Party, 1993). Many guyots are capped by pelagic and shallow-water platform margin and interior sediments that overlie volcanic substrate. The summits and flanks of these guyots contain an archive of relative positions of sea level and of paleoceanographic conditions, and their foundations may contain clues about the volcanic and tectonic histories of the Pacific Plate and the geochemical evolution of the upper mantle beneath the Pacific Ocean.

Seismic reflection profiles over the central portions of these guyots show many continuous reflections, which some researchers suggest represent lagoonal facies sediments, similar to the reflections in Cenozoic atoll lagoons, where drilling has shown that these reflections correlate with emersion surfaces related to lowstands of sea level (Folger, 1986; Wardlaw, 1989). Similar studies of Neogene pelagic sediments of the central equatorial Pacific suggest the correlation among petrophysical properties, seismic reflections, and global oceanographic events, possibly includes changes in sea level (Mayer et al., 1986; Shipley et al., 1983; Shipley et al., 1989; Fulthorpe et al., 1989). In pelagic sediments, diagenetic processes are thought to be partly controlled by oceanographic events attending original deposition, and have been archived as changes in the acoustic properties of the sediment (for an overview, see Winterer, 1991). One of the objectives of Leg 143 was to understand these seismic reflection signatures for comparison with other guyots. Estimates of thickness of the limestone

\footnotetext{
${ }^{1}$ Winterer, E.L., Sager, W.W., Firth, J.V., and Sinton, J.M. (Eds.), 1995. Proc. ODP. Sci. Results, 143: College Station, TX (Ocean Drilling Program).

${ }^{2}$ Department of Earth Sciences, Vrije Universiteit, De Boelelaan 1085, $1081 \mathrm{HV}$, Amsterdam, The Netherlands.
}

successions were based upon identifying the depth of the "acoustic" basement reflection, thought to indicate the contact between limestone and basalt. Note that most seismic profiles are single-channel, water-gun or air-gun source, often towed at high speed (more than 6 $\mathrm{kt}$ ), and typically recorded in analog fashion. Tectonic interpretations of guyot subsidence rely heavily on tracing these basement reflections in seismic lines that cross guyots.

Our aim was to answer questions related to the origin of the reflections within the carbonate succession at Site 866 (Fig. 1), to the possibility of detecting the basement reflection, and the applicability of logs other than velocity and density as proxies for impedance in synthetic seismic experiments on subsurface or outcrop data.

Effective seismic interpretation requires the correlation of seismic data with well data. This is usually accomplished by visually correlating a synthetic seismogram, generated from sonic and density logs, with the seismic profile. One-dimensional synthetic seismograms, especially in a horizontally layered medium, enable us to correlate lithology and associated petrophysical parameters (velocity and density) with seismic reflection profiles (Sheriff and Geldart, 1983). With this information, we may observe which parameters influence or produce seismic reflections, or, which lithologic changes in the guyots will likely be observed in seismic reflection profiles and which will not.

If a sonic $\log$ is not available but a density $\log$ is, then Gardner's equation is generally used to estimate the sonic data. When neither sonic nor density logs are available, techniques have been developed for estimating the sonic traveltime from other well-log data (e.g., the resistivity log; Adcock, 1993). We converted the gamma-ray, resistivity, and neutron porosity logs and discrete measurements from minicores to pseudosonic logs. Synthetic seismograms calculated from these pseudosonic logs were compared with those derived from the sonic and density logs.

A similar approach that has revealed shortcomings of current sequence stratigraphic interpretations is the two-dimensional modeling of seismic-scale outcrop geometries, where both facies and petrophysical properties are measured and converted to synthetic seismic profiles 


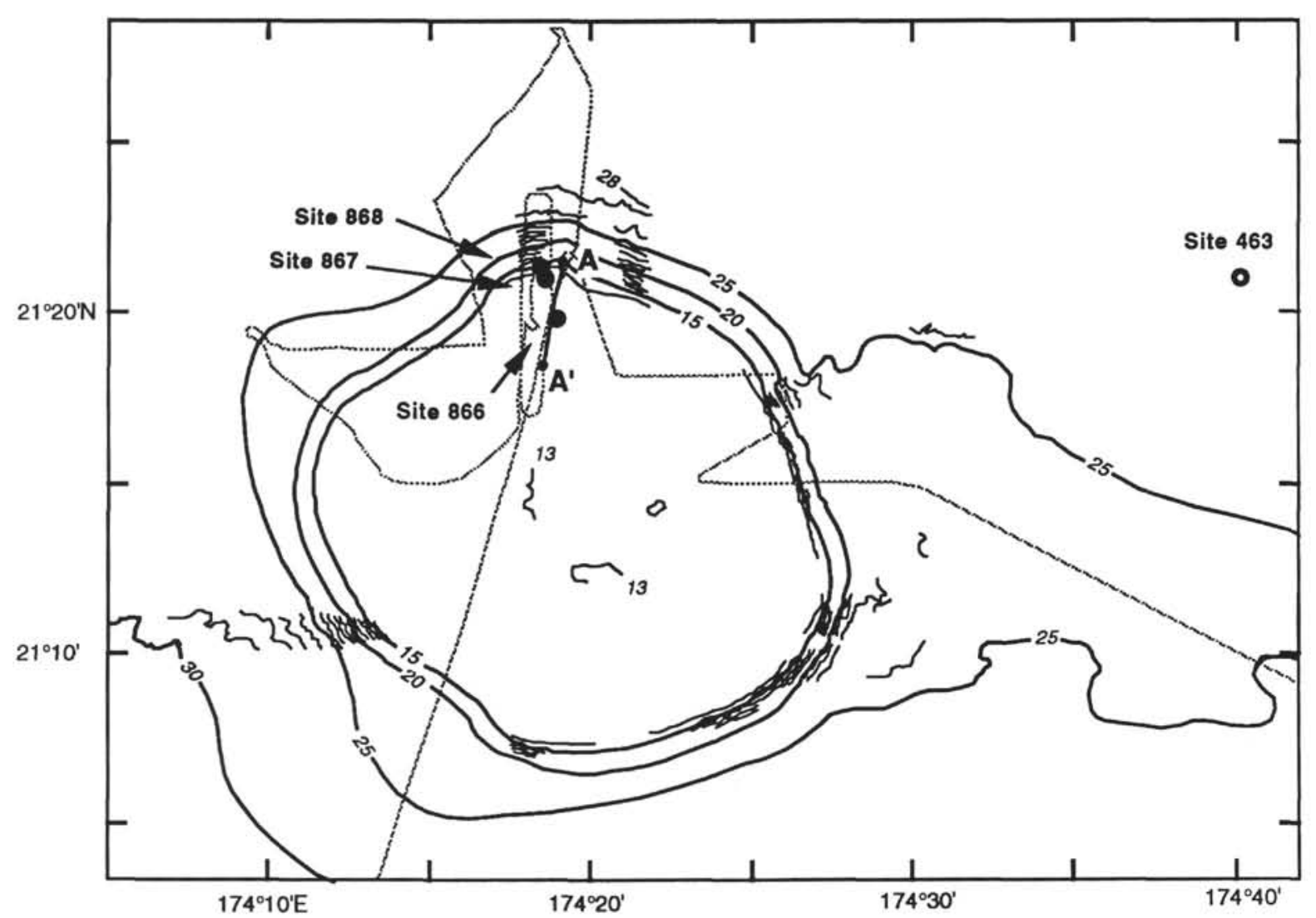

Figure 1. Bathymetry of Resolution Guyot and geophysical ship's tracks (after Sager, Winterer, Firth, et al., 1993). Thin contours shown at 100-m intervals, where SeaBeam multibeam data are available; heavy contours show 500-m intervals. Contours labelled in hundreds of meters. Thin gray lines show path of JOIDES Resolution. A-A' denote ends of seismic reflection profile shown in Figure 3A.

(e.g., Rudolph et al., 1989; Christensen and Szymanski, 1991; Biddle et al., 1992; Campbell and Stafleu, 1992; Stafleu et al., in press). Most critical in these studies is the conversion of outcrop data into a realistic impedance function by directly measuring the acoustic properties of the rocks (discrete measurements) or by defining another variable (e.g., gamma rays or resistivity) that follows the variation of impedance. Using the gamma-ray measurements of outcrops as proxy for impedance, or using the discrete measurements from minicores, we can compare the results with those from sonic and density logs from boreholes and thereby improve methods of converting outcrop data to realistic synthetic seismic models.

\section{GENERAL LITHOLOGY}

At Site 866 , located $1.5 \mathrm{~km}$ behind the margin of Resolution Guyot, a thin pelagic cap and $1620 \mathrm{~m}$ of Barremian-Albian shallowwater, mainly lagoonal, carbonates were drilled before reaching bottom in $125 \mathrm{~m}$ of subaerial basalt flows (Fig. 2). Eight lithologic units were recognized within the sedimentary succession. Unit VIII, the lowest unit, consists of some $202 \mathrm{~m}$ of Barremian and Hauterivian oolitic/oncoidal grainstone having various grades of dolomitization. Dolomitization is typically layered, but also generally decreases upward and becomes patchy at the top of the unit. Unit VII, about $196 \mathrm{~m}$ thick, is Barremian dolomitized ooilitic/peloidal grainstone with algal laminates and clay/organic-rich layers. Unit VI comprises $412 \mathrm{~m}$ of Barremian and Aptian packstone-wackestone with algal laminites, patchy dolomitization, and meter-scale repetitive shallowing-upward sequences. Unit V is about $125 \mathrm{~m}$ thick and consists of Aptian oolitic grainstone to rudstone. Unit IV, about $415 \mathrm{~m}$ thick, again is Aptian packstone-wackestone with clay/organic-rich layers. Unit III consists of $414 \mathrm{~m}$ of Aptian wackestone to mudstone that contains a fraction of clay. Subunit IIIC is dense, tight mudstone. The uppermost Units II and I are, respectively, a thin mineralized limestone capping the platform and the overlying Maastrichtian to upper Pliocene pelagic ooze.

\section{DATA}

A seismic profile passing virtually over Site 866 , on a course of $174^{\circ}$, was shot by the JOIDES Resolution, using a 200 -in. ${ }^{3}$ water gun (Fig. 3A). Data from the single-channel seismic profile were recorded by a Teledyn streamer with a 100 -m-long active section containing 60 hydrophones that were combined to produce a single signal (considering a water depth of approximately $1200 \mathrm{~m}$ ). The streamer was deployed from the fantail and towed about $500 \mathrm{~m}$ behind the JOIDES Resolution at a depth of $10 \mathrm{~m}$. Five seconds of seismic data, characterized by a peak-frequency of approximately $35 \mathrm{~Hz}$, were recorded at a 1-ms sample rate and stored on a magnetic tape ("Underway Geophysics" chapter in Sager, Winterer, Firth, et al., 1993). The seafloor reflection occurs at $1.7 \mathrm{~s}$. Source repetition rates in distance and time were approximately 1 shot $/ 45 \mathrm{~m}$ and 5 shots $/ \mathrm{min}$, respectively. Data were processed for shipboard reference using a Masscomp computer and SIOSEIS software. A zero-phase, 25- to $100-\mathrm{Hz}$ bandpass filter was applied. Other processing parameters include a threetrace, equally weighted, running slant mix and automatic gain control with a window of $500 \mathrm{~ms}$. Despite reprocessing at the University of Hawaii using the SSC software, the quality of the digital seismics could not be improved ("Underway Geophysics" chapter, Fig. 6, in Sager, Winterer, Firth, et al., 1993).

Downhole measurements included sonic velocity, neutron density, neutron porosity, natural gamma-ray, and resistivity logs. Data on gamma-ray, sonic velocity, neutron porosity, and resistivity were 


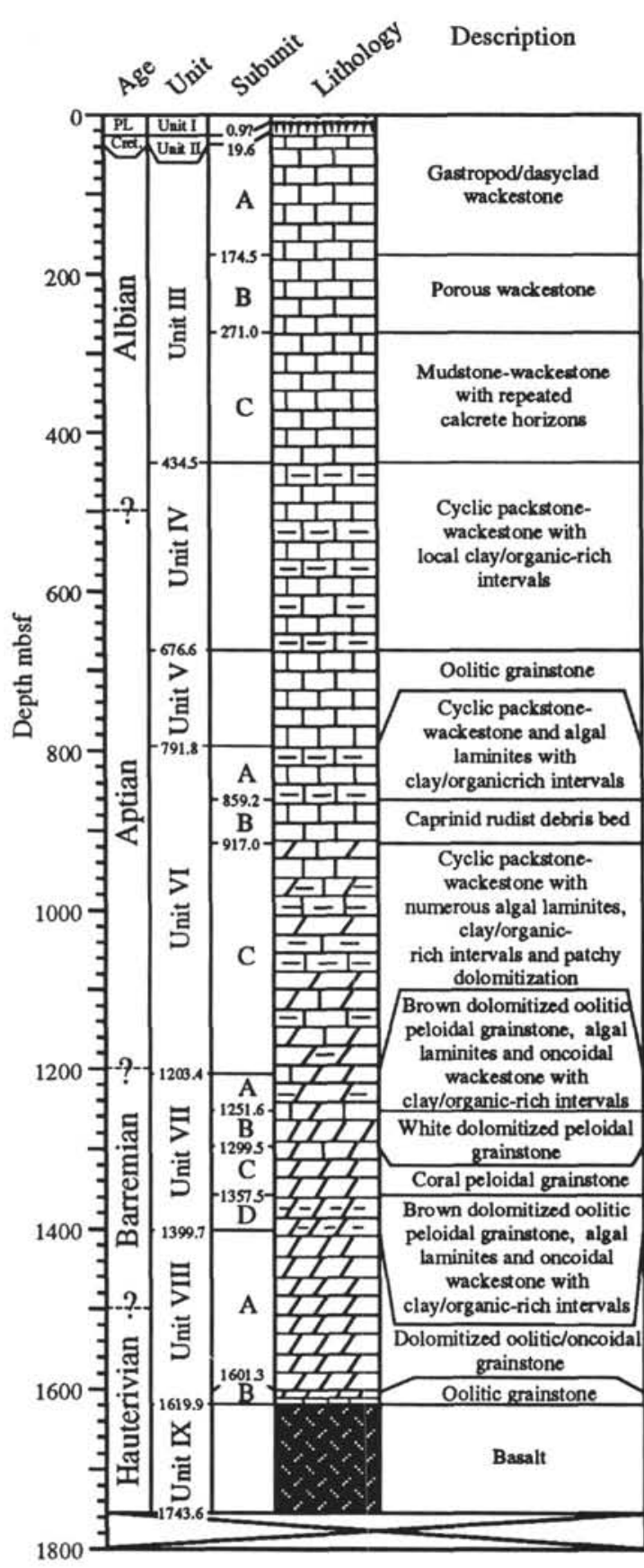

Rock and sediment type

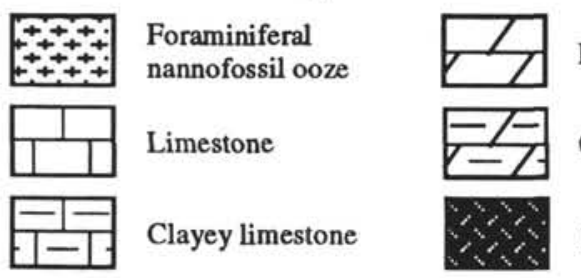

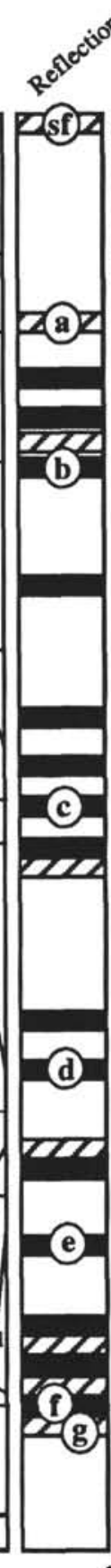

Bulk density $\left(\mathrm{g} / \mathrm{cm}^{3}\right)$ from neutron density $\log$

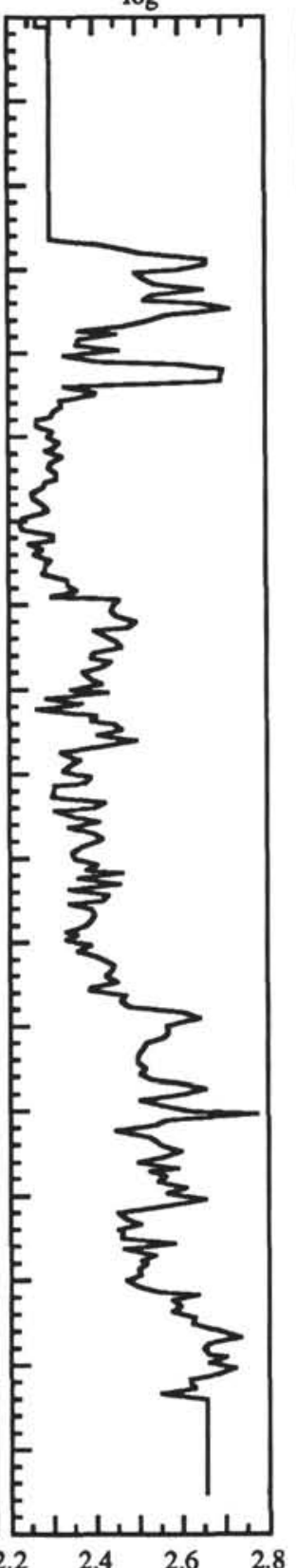

Sonic velocity

$(\mathrm{km} / \mathrm{s})$
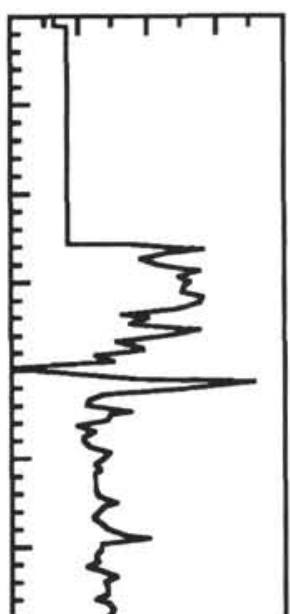

$=3$

E

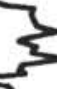

$E$
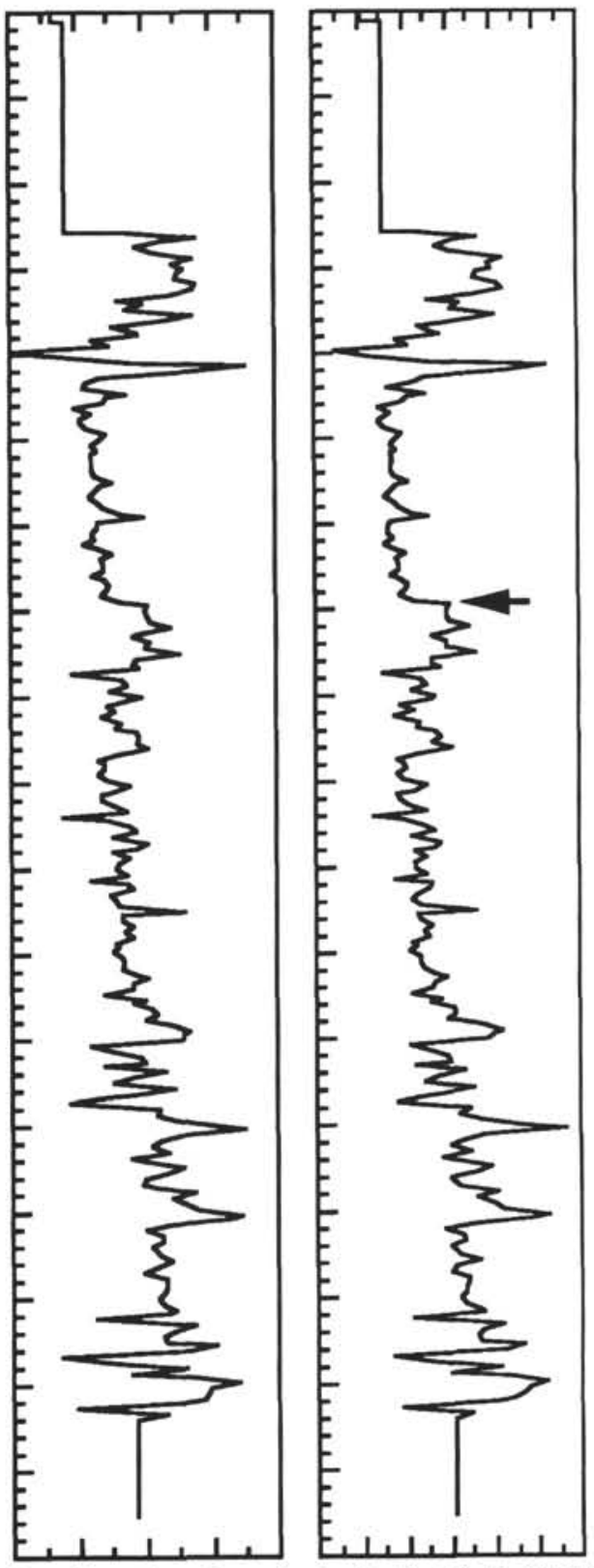

Reflections synthetic seismogram $V_{p^{*}} \rho$ (Fig. 5)

Dolomite

Negative reflection event

ZZ Positive reflection event

Clayey dolomite

Basalt

Figure 2. Simplified lithologic column (Sager, Winterer, Firth, et al., 1993) along with smoothed and resampled (see text) logs of sonic velocity, neutron density, and acoustic impedance function derived from log velocity and neutron density. In the middle column, horizontal bars, labeled with a character, represent reflections from the synthetic seismograms calculated from sonic velocity and density. Filled bars indicate reflections that correlate with a lithologic change; hachured bars indicate reflections that have no correlative lithologic change; $\mathrm{sf}=$ seafloor reflection (see text for discussion). 
A

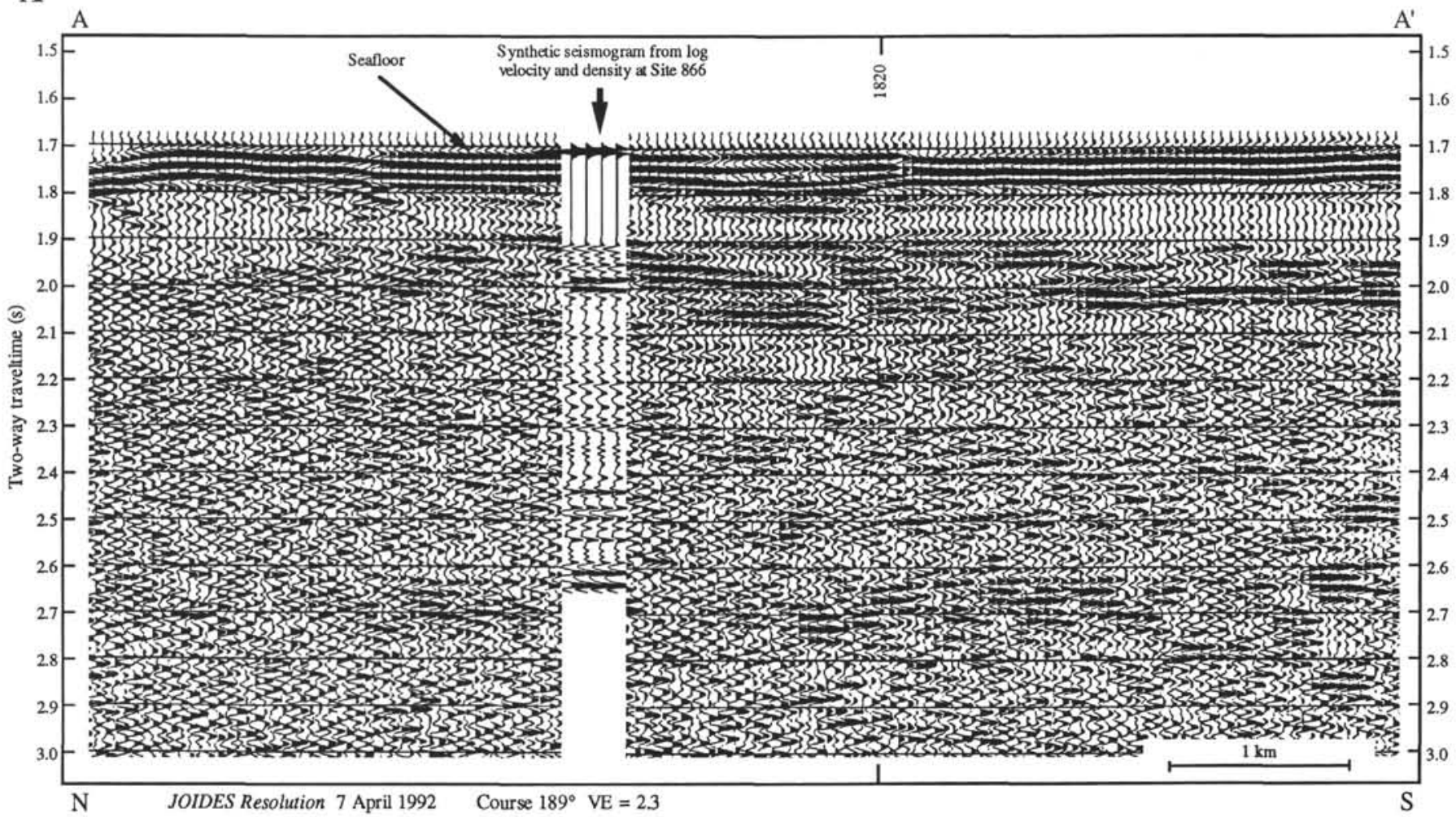

Figure 3. Synthetic seismogram based on sonic and density logs spliced into seismic line at location of Site 866 (A) and interpreted reflection pattern (B). The shaded areas (Fig. 3B) between about 1.9 and 2.08, and between 2.6 and $2.7 \mathrm{~s}$ TWT represent zones having relatively "continuous" bundles of reflections (visible in Figs. $3 \mathrm{~A}$ and $\mathrm{BB}$ ). Arrow indicates impedance change that has not been "recorded" by reflections, possibly because of destructive interference (see text for discussion).

obtained in one single run using the combined geophysical tool string. The gamma-ray tool measures the natural radioactivity of the formation. The gamma-ray radiation of the formation is measured by a scintillation detector and separated into those emitted by $\mathrm{K}, \mathrm{U}, \mathrm{Th}$, and total gamma ray. The vertical resolution of the log is approximately $0.46 \mathrm{~m}$. Gamma-ray is usually a proxy for the abundance of clay minerals, volcanic ash, or potassic feldspar.

The long-spaced sonic tool measures the time required for sound waves to travel over source-receiver distances of $2.4,3.0$, and $3.6 \mathrm{~m}$. The raw data are recorded as time required for a sound wave to travel through $0.31 \mathrm{~m}$ of formation. These traveltimes are converted to sonic velocities in kilometers per second. The vertical resolution of the sonic tool is $0.6 \mathrm{~m}$. Compressional wave velocity in carbonates is dominantly controlled by porosity, carbonate mineralogy, and clay content.

The phaser induction tool (DIT) provides measurements of electrical resistivity at three different depths in the formation. Two induction devices create magnetic fields that induce secondary currents in the formation, which are recorded by the receiving coils. Measured conductivities then are converted to resistivity. We used the spherically focussed resistivity $\log$ (SFLU), which has a vertical resolution of about $0.76 \mathrm{~m}$. Resistivity is largely controlled by water content, salinity, concentration of hydrous and metallic minerals, and the geometry of interconnected pore space.

The dual-porosity neutron tool provides a measure of the hydrogen content by comparing the flux of neutrons returning to detectors at different distances from the source. The neutron porosity tool has a vertical resolution of approximately $0.25 \mathrm{~m}$.

Each of the petrophysical properties and acoustic properties from the minicores and the wireline logs was used to estimate sonic velocity for input in the synthetic seismograms to compare with the seismic reflection profile.

\section{METHODS}

\section{Editing of Logs}

For the purpose of seismic modeling, we edited the original log data to produce standardized logs for input in the synthetic seismograms. The original (digital) log data have a spacing of $0.15 \mathrm{~m}(0.5$ $\mathrm{ft}$ ). Data showed considerable short-term fluctuations and high frequency noise reflected as extremely low or high readings. Short-term fluctuations were removed by applying a five-point $(0.61 \mathrm{~m}$ or $2 \mathrm{ft})$ moving average window. High frequency noise occurred particularly in the sonic log, owing possibly to cycle skipping or noise interference (Sager, Winterer, Firth, et al., 1993). Extremely low (e.g., less than $1.5 \mathrm{~km} / \mathrm{s}$ ) and high values (e.g., more than $6.5 \mathrm{~km} / \mathrm{s}$ ) were removed from the data. This resulted in virtually all the data between a depth of 0 and $253 \mathrm{~m}$ being removed, suggesting that the few remaining data in this interval are not reliable. Large hole diameters, exceeding 17 in. $(0.43 \mathrm{~m})$, account for questionable density/porosity data in the same interval (see caliper log, Sager, Winterer, Firth, et al., 1993). Therefore, we decided to use an average velocity of $2.83 \mathrm{~km} / \mathrm{s}$ $(9290 \mathrm{ft} / \mathrm{s})$, the calculated average of the remaining data after removal of the extremely high and low values, was used for the upper $253 \mathrm{~m}$. Finally, all $\operatorname{logs}$ were resampled to a $6-\mathrm{m}(20-\mathrm{ft})$ interval by averaging data over $\pm 3 \mathrm{~m}$ ( $10 \mathrm{ft})$. At the dominant frequency of $35 \mathrm{~Hz}$ and 3.0 $\mathrm{km} / \mathrm{s}$, this sample increment gives approximately 14 samples per wavelength. Log editing thus resulted in five logs of 229 data points each, spanning the interval from 253 to $1637 \mathrm{~m}$.

Data from the sonic and the neutron density logs were multiplied together to construct an acoustic impedance log (see Fig. 2), which we used in the modeling program. Sonic velocity (in kilometers per second) was calculated from the long-spacing transit time sonic log $(12-10 \mathrm{ft}$; in microseconds per foot). 


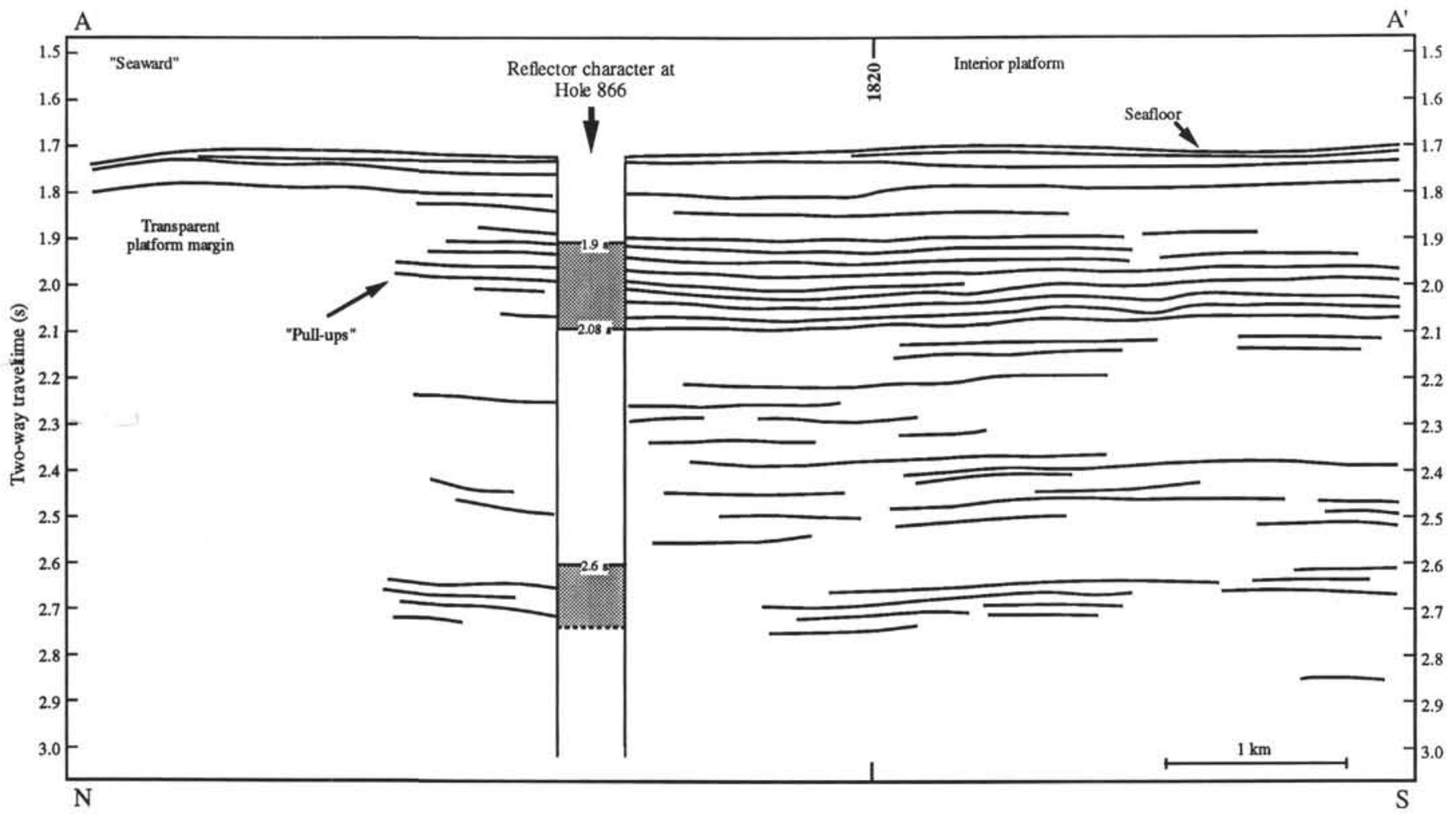

Figure 3 (continued).

Density from the neutron-density log was converted into sonic velocity using the empirical Gardner's equation (Nafe and Drake, 1963; Gardner et al., 1974),

$$
\rho=0.31 \cdot V_{p}^{0.25},
$$

or

$$
V_{p}=108.28 \cdot \rho^{4}
$$

where $V_{p}$ is the $P$-wave velocity (in meters per second) and $\rho$ is the bulk density (in grams per cubic centimeter).

According to Wyllie et al. (1958), the $P$-wave velocity of a rock is a function of porosity and the $P$-wave velocity of the matrix and pore fluid. The pore space was assumed to be filled with seawater. $P$-wave velocities were derived from the empirical equation of Wyllie's "time average equation" (Wyllie et al., 1958),

$$
1 / V_{p}=\phi / V_{\text {fluid }}+(1-\phi) / V_{\text {marrix }},
$$

where $\phi$ is porosity, $V_{\text {fluid }}$ or $V_{\text {seawater }}$ is $1.5 \mathrm{~km} / \mathrm{s}$, and $V_{\text {matrix }}$ is the sonic velocity of the rock matrix (for limestones, $6.4 \mathrm{~km} / \mathrm{s}$; Carmichael, 1989). Figure $4 \mathrm{~A}$ shows a cross plot of velocity calculated from the neutron-density log (using Gardner's equation) and from the neutronporosity $\log$ (using the time average equation) vs. velocity measured on the sonic log.

The spherically focussed resistivity $\log$, with a radial depth of investigation of approximately $0.38 \mathrm{~m}$, was converted to sonic velocity using the equation,

$$
V_{p}=3.5+0.055 \cdot R,
$$

where $R$ is resistivity (in $\Omega \mathrm{m}$ ) and $V_{p}$ is in kilometer per second. This equation was empirically derived from a cross plot between log velocity and resistivity (Fig. 4B).
The natural gamma-ray log was converted to velocity by cross plotting with the sonic log velocity (Fig. 4C),

$$
V_{p}=4.03+0.008 \cdot G
$$

where $G$ is total gamma ray counts (in API units).

The poor correlation of both resistivity and gamma-ray with velocity is expected to result in poor correlation among the calculated synthetic seismograms as well.

\section{Discrete Measurements of Minicores}

Discrete measurements of $P$-wave velocity, under effective pressure, and bulk density were used to construct a blocked impedance function. Moving down the core, each discrete impedance value defines an interval having similar impedance until a new value is reached. The value and the vertical thickness of the impedance blocks, therefore, are controlled by the sample interval or, indirectly, by the recovery.

Forty vertically oriented minicores were collected during Leg 143 from cores from Site 866 . $P$-wave velocity was measured in the petrophysics laboratory of the Royal School of Mines, Imperial College, London. Samples were trimmed to approximately 0.75 to 1.5 in. $(1.9-3.8 \mathrm{~cm})$ long, and sample ends were ground flat and parallel. Each specimen was assembled between brass end pieces within a nitrile rubber jacket of a Hoek triaxial test cell. Lead foil, 0.04-mm-thick disks were placed between each end piece and the rock specimen to provide the acoustic coupling necessary for $S$-wave measurements. We applied effective pressures for simulating the in-situ stress conditions. For the rock specimens from Site 866, the in-situ hydrostatic-stress conditions range from 5 to $40 \mathrm{MPa}$. The precision of the $P$-wave velocities, taking into account the combined effect of inaccurate readings of the first arrivals and consolidation of highly porous samples, is limited to within approximately $3 \%$. Temperature during measurements varied between $18^{\circ}$ and $20^{\circ} \mathrm{C}$. The effect of the slightly elevated 
Figure 4. A. Crossplot of velocity calculated from the neutron-density log (using Gardner's equation) and the neutron-porosity log (using Wyllie's equation) vs. velocity measured on sonic log. B. Crossplot of velocity calculated from the resistivity and original sonic logs. C. Crossplot of velocity calculated from the gamma-ray data and log velocity (see text for discussion)
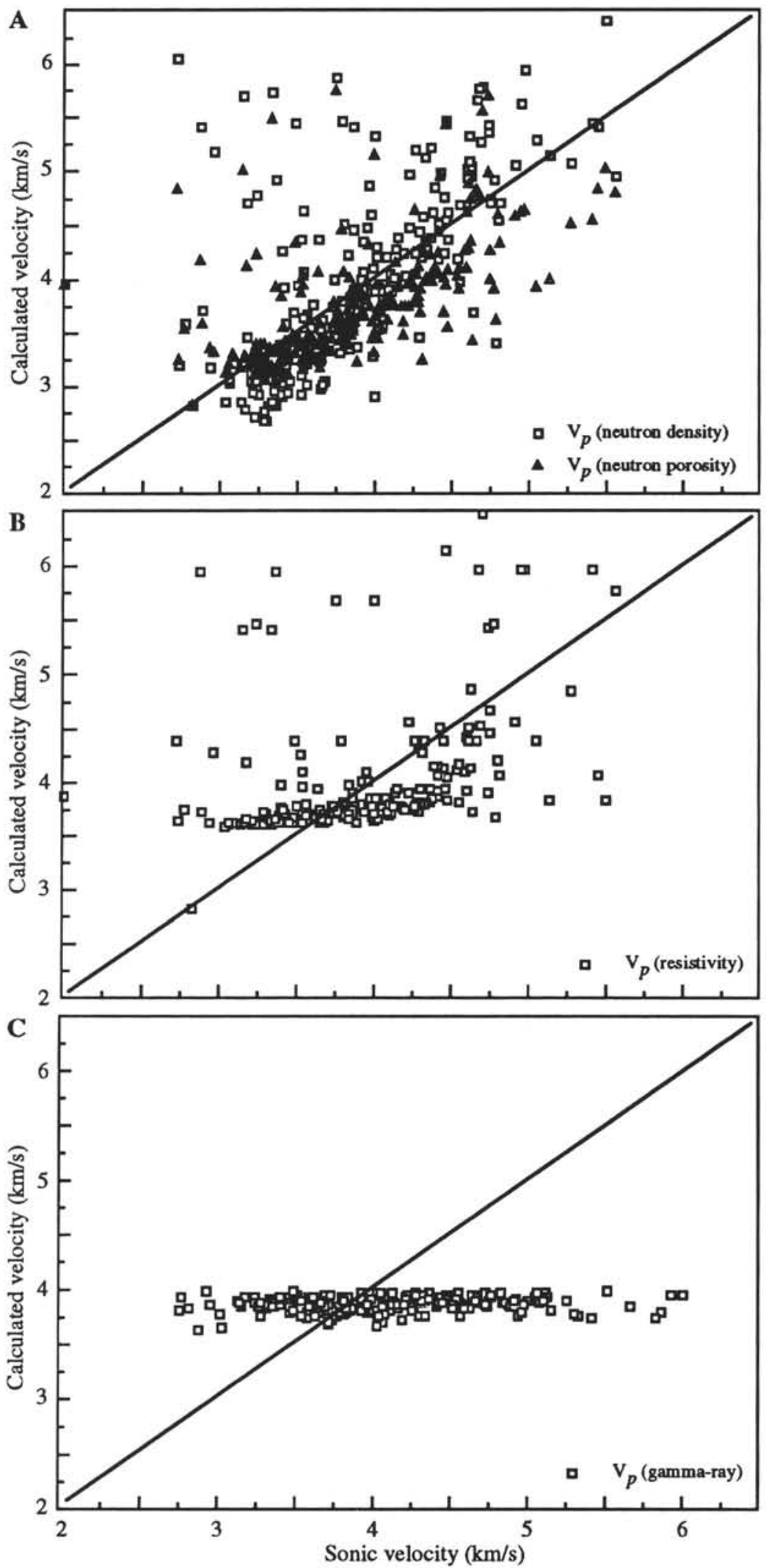
temperature during laboratory measurements of the acoustic properties is assumed to be minimal and probably less than $1 \%$ (Bourbié et al., 1987; Carmichael, 1989). Measurements of the index properties, bulk density, grain density, and porosity of the minicores were performed at the petrophysics laboratory at Vrije Universiteit. Measurements and a detailed description of the methods are listed in Kenter and Ivanov (this volume). Acoustic impedance values of sediments from Site 866 range from $6.8 \times 106$ to $18.4 \times 10^{6} \mathrm{~kg} / \mathrm{m}^{2} / \mathrm{s}$.

The resulting pseudo-impedance log contains 40 irregularly spaced data points, at depths ranging from 281.7 to $1739.6 \mathrm{mbsf}$ (or 924 to $5707 \mathrm{ft}$ ). From the first modeling runs, it was obvious that velocities measured from minicores were consistently higher than velocities derived from the sonic log (Kenter and Ivanov, this volume). To improve the correlation of the synthetic seismogram, based on the minicores with the other synthetic traces as well as with the seismic profile, all the (minicore) velocities were decreased by the dividing the values by a factor of 1.125 . One of the primary reasons that discrete velocities are consistently higher than the log velocities has been suggested to be the preferential selection of higher-velocity lithologies owing to the low recovery.

\section{Construction of One-dimensional Synthetic Seismograms}

A seismic trace can be expressed as the convolution of a source wavelet with the Earth's reflectivity, determined by the distribution of velocity and density (Sheriff and Geldart, 1983). For constructing the one-dimensional synthetic seismograms, we assumed various things to simplify the calculation involved. First, only vertical travel was allowed, and dip was neglected. Reflection coefficients thus are those for vertical incidence,

$$
R_{i}=\left(Z_{i+1}-Z_{i}\right) /\left(Z_{i+1}+Z_{i}\right)
$$

where $R_{i}$ is the reflection coefficient at interface $i$, and $Z_{i}$ and $Z_{i+1}$ (in $\mathrm{kg} / \mathrm{m}^{2} / \mathrm{s}$ ) are acoustic impedances on opposite sides of the interface. Second, diffractions and other modes, such as peg-leg multiples, were ignored. Third, amplitude-changing factors, other than those involving reflection coefficients (e.g., spherical spreading, attenuation, transmission losses), were ignored. Thus, it is inappropriate to use automatic gain control (AGC) in the construction of the synthetics. Because AGC was applied to the real seismic record (using a window of $500 \mathrm{~ms}$ ), this third assumption may influence the correlation of real and synthetic data.

A fourth factor commonly assumed is to ignore density variation and to use the (pseudo)-sonic logs only. In the above-mentioned equation, $Z$ then is replaced by $V_{p}$. This study presents synthetic seismograms both with and without incorporating this fourth simplification.

The (pseudo)-sonic velocities were used to convert the reflection coefficient series from depth to two-way traveltime (TWT). A zerophase, 25 - to $100-\mathrm{Hz}$, bandpass filter (peak frequency, $\pm 35 \mathrm{~Hz}$ ), similar to the filter applied when processing the real seismic data, was convolved with the reflectivity series:

$$
S(\mathrm{~m})=\sum_{\mathrm{n}=1}^{\mathrm{N}} R(\mathrm{n}) \cdot W(\mathrm{~m}-\mathrm{n}+1)
$$

where $W$ represents the bandpass wavelet, $S=$ the resulting seismic trace, and $R=$ the $\log$ of reflection coefficients expressed in $1-\mathrm{ms}$ sample increments. Negative reflection events (i.e., downward continuations to a lower velocity or impedance) have been plotted in black (reverse polarity convention also is displayed in seismic reflection profile, Fig. 3A, the same convention as Fig. 5). Each synthetic trace was repeated four times.

\section{RESULTS}

\section{General}

Figure $3 \mathrm{~A}$ shows the seismic reflection profile recorded by the JOIDES Resolution during the pre-drilling site survey of Resolution Guyot. Another seismic reflection profile, recorded by the Thomas Washington during the Roundabout Leg 10 site-survey cruise, was not selected for this study, although it indicates a complete transect over the guyot, as that profile has fewer laterally continuous reflections below $1.9 \mathrm{~s}$ TWT (see Sager, Winterer, Firth, et al., 1993). For the JOIDES Resolution, the seismic source was a 200 -in. ${ }^{3}$ water gun. Spliced into the seismic line in Figure $3 \mathrm{~A}$ is the synthetic trace calculated from log velocity and log density (Fig. 5).

The seismic profile does not allow for the tracing of individual reflections. However, two zones of relatively continuous and highamplitude reflections that both disappear (or show "pull ups" probably related to somewhat higher velocities in the margin) into the direction of the margin, were observed and have been indicated in the interpretation in Figure 3B. The upper reflection unit is between 1.9 and $2.08 \mathrm{~s}$ TWT, and the lower reflection unit is between 2.6 and about $2.73 \mathrm{~s}$ TWT. The high-amplitude reflections in the upper interval show some discontinuous relationships as well that may be related to recording quality.

The synthetic trace in Figure 3A, calculated from the velocity and density logs, shows little correlation with the seismic reflection profile. The two high-amplitude reflections, at 1.98 and $2.01 \mathrm{~s}$ TWT, are located at about two-thirds of the way through the upper reflection unit, whereas the lower two high-amplitude reflections, at 2.62 and $2.64 \mathrm{~s}$ TWT, correlate with the top of the lower reflection unit in Figure $3 \mathrm{~B}$. Between the two reflection units, few laterally continuous reflections are visible in the seismic profile, although the synthetic seismogram has several distinct high-amplitude reflections. The reflection at $2.2 \mathrm{~s}$ TWT on the synthetic trace correlates with a fairly continuous reflection at similar depth in the seismic profile. The four high-amplitude reflections at 2.44,2.47, 2.50, and 2.54 s TWT on the synthetic trace have no analogs in the seismic reflection profile.

Figure 5 shows the seismic trace at Hole $866 \mathrm{~A}$, along with the reflection units from Figure $3 \mathrm{~B}$ and the synthetic seismogram calculated from $l o g$ velocity and density. Indicated are reflections from the synthetic seismogram that have significant amplitude. Those reflections that correlate with lithologic changes are labelled by a character. Figure 6 shows a comparison of the synthetic seismograms that were calculated from the various $\log$ variables with discrete measurements of density and velocity. The synthetic seismograms in Figure 6A have been calculated from velocity only, whereas the synthetic traces in Figure $6 \mathrm{~B}$ are calculated from velocity and density. On the left of each of the synthetic seismograms, we have plotted an impedance curve and reflection coefficient.

\section{Synthetic Seismograms: Lithology and Seismic Reflection Profile}

Prominent reflections from the synthetic seismic trace, calculated from log velocity and density (Fig. 5), were plotted next to the lithologic column in Figure 1. The sharp and positive reflection a and negative reflection $\mathrm{b}$, respectively, at 1.91 and $2.0 \mathrm{~s}$ TWT, coincide with the top and bottom of lithologic Subunit IIIC, massive and dense mudstone-wackestone, overlain by porous wackestone of Subunit IIIB and underlain by clayey packstone-wackestone of Unit IV. The highamplitude positive reflections at $1.94,1.98 \mathrm{~s}$ (see Fig. 6B), and $1.99 \mathrm{~s}$ TWT, correspond to abrupt changes in acoustic properties, but have no observed corresponding lithologic boundaries. Similarly, reflections (positive and negative) between 2.1 and $2.41 \mathrm{~s}$ TWT, have correlative changes in acoustic properties, but no observed lithologic changes. The 
Figure 5. Seismic trace at Site 866 along with the synthetic seismogram calculated from log velocity and density. The column in the middle has horizontal bars that represent reflections from the synthetic trace; each reflection with significant amplitude has been labeled with a character ( $\mathrm{sf}=$ seafloor reflection). Reflections that have correlative lithologic changes have been filled, others are hachured. Reflection units from Figure 3B have been indicated as well (see text for discussion).

position of reflection $\mathrm{c}$ at $2.25 \mathrm{~s}$ TWT, correlates to the lithologic change from Subunits VIA to VIB, from packstone-wackestone to a rudist-bearing interval. Alternatively, the abrupt increase in impedance at $2.15 \mathrm{~s}$ TWT, the change from lithologic Units IV to V, has no corresponding reflection (see Figs. 2 and 5). Reflection d at $2.44 \mathrm{~s}$ TWT correlates with an abrupt lithologic change from Subunit VIC, packstone-wackestone with algal laminites and clay-rich intervals, to the underlying Units VII and VIII, generally dolomitized oolitic to peloidal and oncoidal grainstone. High-amplitude reflections (positive and negative) between 2.47 and $2.64 \mathrm{~s}$ TWT coincide with changes in degree of dolomitization, rather than primary depositional texture. Of these, reflections e (negative) and f (positive), at 2.54 and $2.63 \mathrm{~s}$ TWT, correlate to the transition from Subunits VIIIA to VIIIB, the transition from limestone to the "altered" top of the underlying basalt, respectively. The negative reflection g, at $2.64 \mathrm{~s}$ TWT, corresponds to the transition within the top of Unit IX, from the altered top to the "unaltered" underlying succession of subaerial basalt. Some of the reflections mentioned above that have no correlative lithologic changes may be the result of interference (e.g., Fig. 5, the positive

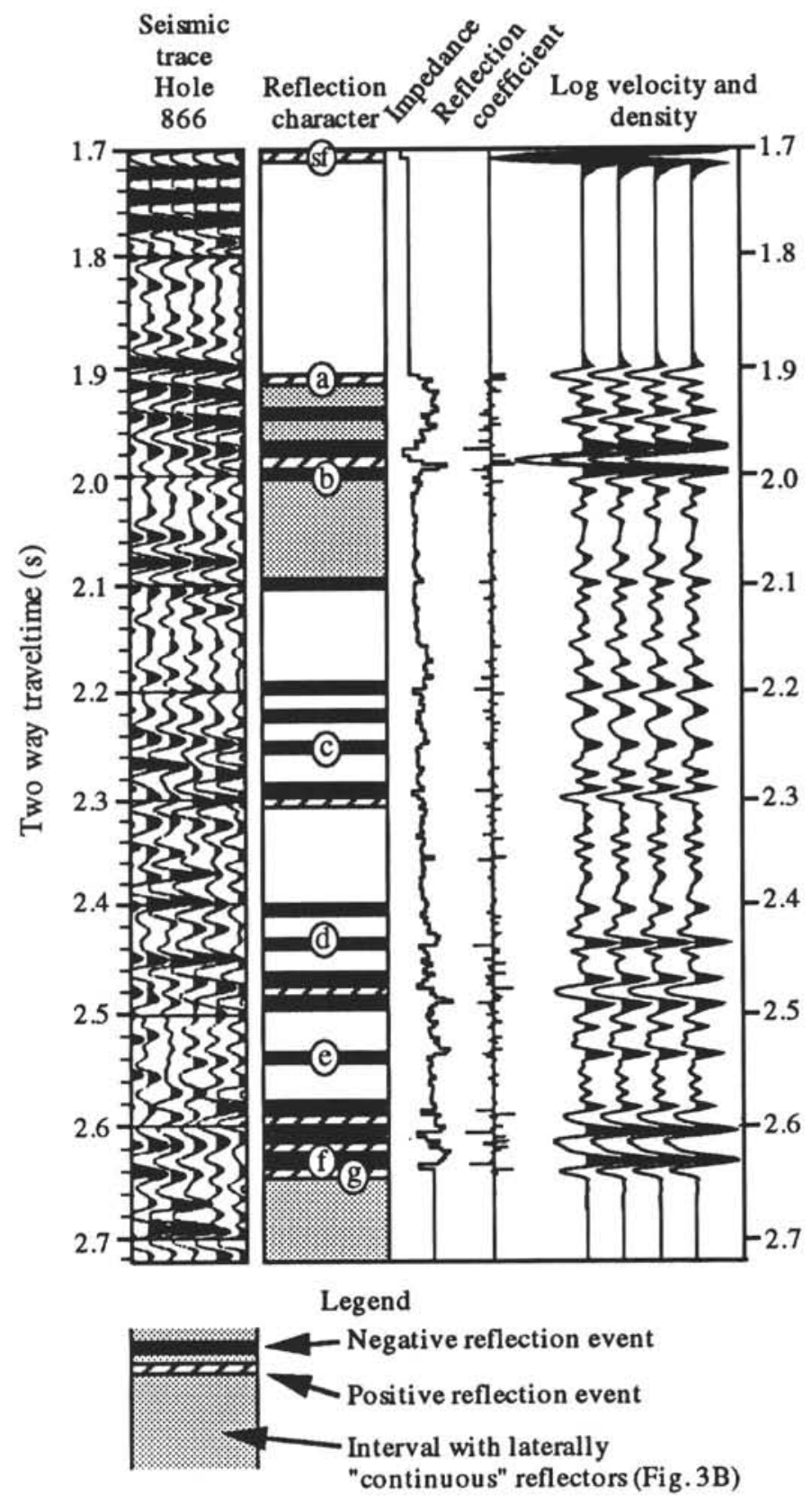

reflection at $2.47 \mathrm{~s}$ TWT has no distinct reflection coefficient and is likely the cumulative effect of many smaller impedance changes).

In summary, the correlation between the synthetic seismograms and the reflection profile is generally poor (Fig. 3A). Reflection a, transition Subunits IIIB to IIIC, corresponds to the top of the upper reflection unit on the seismic reflection profile (Fig. 3B). The top of the lower reflection unit correlates to the reflection at $2.61 \mathrm{~s}$ TWT, and probably is related to an impedance change caused by dolomitization within Unit VIII. Other reflections that are related to unit boundaries have no distinct correlative reflection in the seismic profile.

\section{Experimental Synthetic Seismograms}

Figure $6 \mathrm{~A}$ shows the comparison between synthetic seismograms calculated from the various logs as proxy for velocity, while density was held constant. Figure 6B adds (neutron) density to the impedance function.

The synthetics calculated from neutron density and neutron porosity are comparable, but exhibit several relative shifts of reflections 


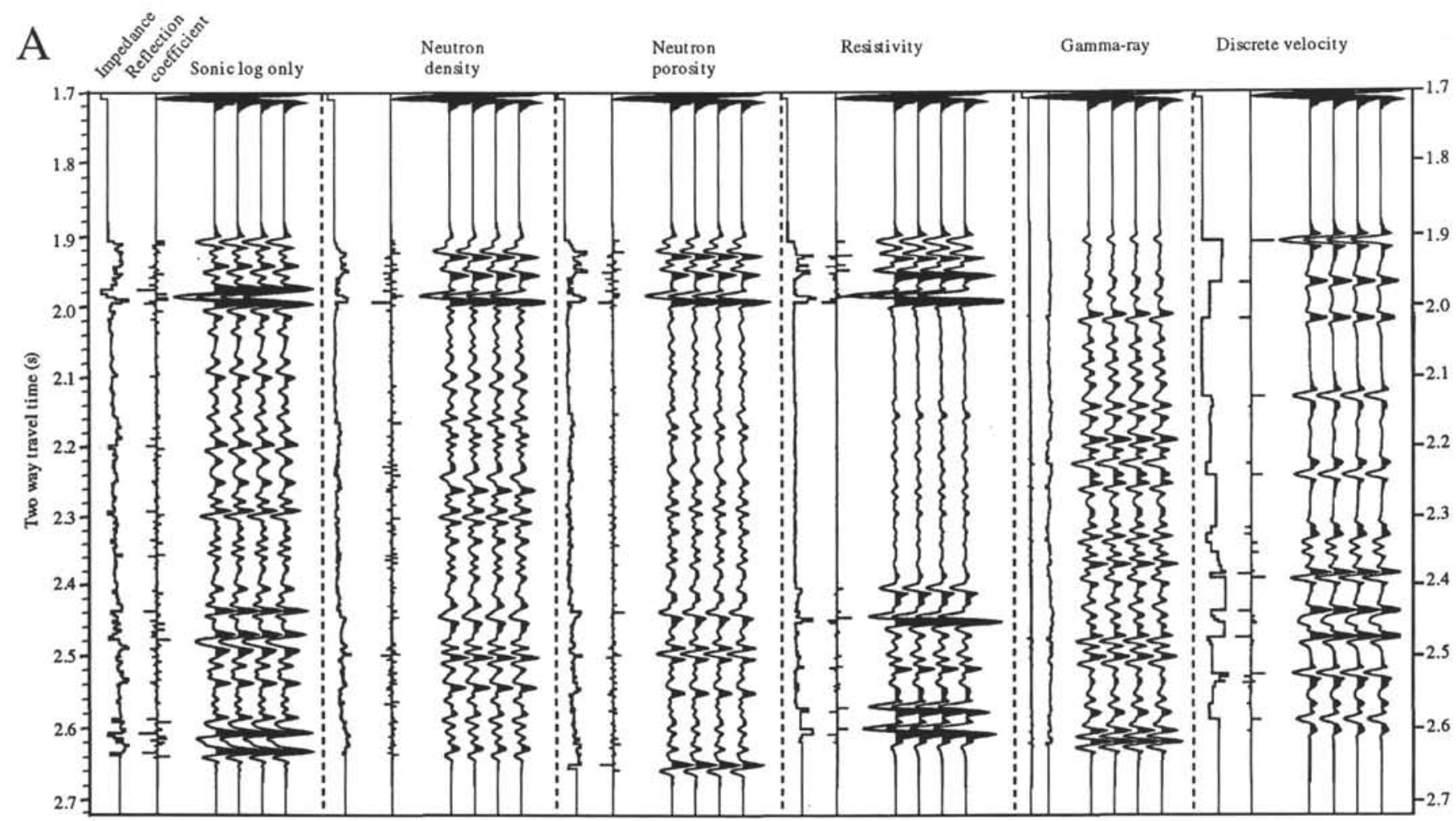

Figure 6. Comparison of the various synthetic seismograms that were calculated from log velocity, neutron density, neutron porosity, resistivity, and gamma-ray, and discrete measurements of velocity and density. A. Synthetic traces calculated from velocity (or pseudo-velocity); density was held constant. B. Synthetic traces from both velocity and density. To the left of the synthetic seismograms are plotted the impedance curve and reflection coefficient (see text for discussion).

with respect to their position in the synthetic trace, based on velocity. Reflections a (1.91 s), c (2.25 s), and e (2.54 s) were shifted downward, whereas reflection $\mathrm{d}(2.44 \mathrm{~s})$ changed from negative to positive in the synthetic traces calculated from density and porosity. Overall, velocities converted from neutron porosity are slower, compared to sonic velocity and velocity derived from density, as the synthetic trace is about $0.2 \mathrm{~s}$ longer. Velocity calculated from the resistivity log produces a synthetic seismogram that shows only the high impedance contrasts, but has no high-amplitude reflections between 2.0 and 2.41 s TWT. Still, the match with the synthetic that is based on log velocity is unexpectedly good, given the low correlation in Figure 4B. The synthetic calculated from the gamma-ray log shows only reflection b $(2.00 \mathrm{~s})$ and mainly noise in the remaining part, as expected from Figure 4C. The synthetic trace calculated from discrete velocity measurements shows a series of high-amplitude reflections, some of which correspond to lithologic changes, but have shifted upward or downward because of the limited data set. The large positive reflection at $2.13 \mathrm{~s}$ in the synthetic trace (discrete velocity) probably correlates to the lithologic transition from Units IV to V. This lithologic transition has also been resolved in the synthetic seismograms calculated from the neutron density and porosity logs, but not in the synthetic derived from the sonic log.

Besides the increase of amplitude of reflections, only minor changes are observed in the synthetics calculated from sonic velocity, neutron density, and neutron porosity in Figure 6B when compared to those in Figure $6 \mathrm{~A}$. The reflections in the synthetic trace derived from resistivity have significantly increased amplitude, and reflections are visible in the (Figure 6A transparent) interval between 2.0 and $2.41 \mathrm{~s}$ TWT. The synthetic trace calculated from the gamma-ray log shows reflections related to the major lithologic transitions (reflections $\mathrm{a}, \mathrm{b}$, $\mathrm{c}, \mathrm{f}$, and $\mathrm{g}$ ). The reflection in the synthetic seismogram derived from discrete measurements of velocity and density has increased amplitude, but otherwise shows no change.

\section{DISCUSSION}

The correlation between the synthetic seismogram (derived from sonic velocity and neutron density) and the reflection pattern in the seismic reflection profile is poor. Several causes may explain this mismatch: quality of recording, laterally discontinuous distribution of acoustic properties from diagenetic variability, and destructive interference (e.g., the lithologic transition from Units IV to V). The question of continuity of depositional or diagenetic facies, and possibly lithologic layers that are related to changes in sea level or oceanographic events, is more difficult to solve. One significant difference between the seismic reflection profile and synthetic seismograms is the presence of a chaotic reflection zone in the synthetic trace between 1.9 and $2.09 \mathrm{~s}$ TWT that has continuous high-amplitude reflections in the seismic profile. Whether this is the result of rapid lateral lithologic facies (e.g., washover deposits, with consequent changes in acoustic properties) or recording quality remains unclear. The mainly transparent margin and the presence of "pull ups" (Fig. 3B) may be related to a predominance in this zone of high-velocity (consequently, highimpedance), well-cemented grainstone and rudstone. The "reefmargin" facies then may well consist primarily of cemented sand shoals (see Sager, Winterer, Firth, et al., 1993).

Synthetic seismograms may provide an answer as to which lithologic transitions may be indicated on a reflection profile. Several significant lithologic transitions have correlative reflection events (e.g., reflections a, b, d, e, and g), but a similar number of highamplitude reflections, especially deeper in the core, probably are related to changes in character of dolomitization and others to interference (no unique corresponding reflection spike). One lithologic transition, from Units IV to $\mathrm{V}$ and possibly related to changes in relative sea level of oceanographic events, is not visible in the synthetic seismogram because of the earlier-mentioned effect of destructive interference. 


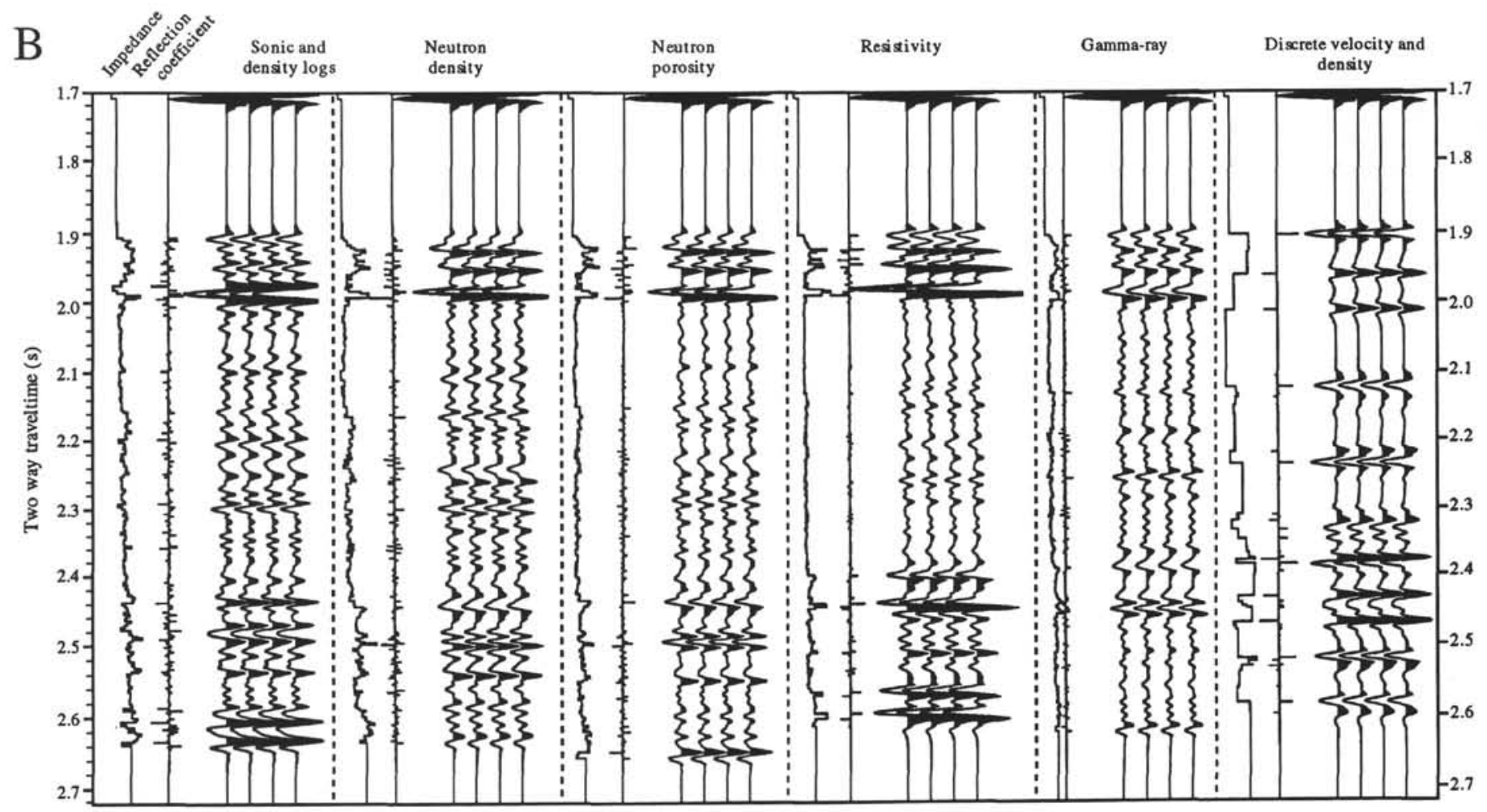

Figure 6 (continued).

The transition from limestone to basalt cannot be seen well and has a low amplitude, because impedance contrasts within the limestone succession are equal to, or higher, than that between limestone and basalt. Furthermore, an uncertainty exists in the impedance values of the basalt. Marine basalts, unaltered, may have impedance values between 12 and $18 \times 10^{6} \mathrm{~kg} / \mathrm{m}^{2} / \mathrm{s}$ (Charmichael, 1989). Impedance values from the sonic and density logs are about $10 \times 10^{6}$ $\mathrm{kg} / \mathrm{m}^{2} / \mathrm{s}$, whereas values from discrete measurements range between 10.8 and $16.4 \times 10^{6} \mathrm{~kg} / \mathrm{m}^{2} / \mathrm{s}$ (including measurements of samples from the deeper, not logged, portion of the basalt interval; see Kenter and Ivanov, this volume). Using higher impedance values for the basalt may enhance reflection $\mathrm{g}$, whereas, on the other hand, only the presence of marine, fresh, and unaltered basalt may produce a distinct reflection. Note that in Hole $866 \mathrm{~A}$ subaerial basalt flows, not marine basalt, were penetrated. In the latter case, the basement should be identified as a transition from a continuous reflection pattern to a reflection-free zone.

Several conclusions can be drawn from the construction of synthetic seismograms with sonic velocity and other wireline log data as input. First, using neutron density and neutron porosity as input for velocity causes a relative downward shift of some reflections and, in some cases (e.g., reflection d), an inversion of the reflection. The conversion from density to velocity, using Gardner's equation (Gardner, 1974) is accurate, whereas the conversion of porosity to velocity, using Wyllie's equation (Wyllie et al., 1958) with appropriate matrix velocities yields values of velocity that are too low (Fig. 4A). The correlation among velocity, resistivity, and gamma rays is poor (Figs. 4B and 4C). On average, clay content is low at Site 866 (Sager, Winterer, Firth, et al., 1993), and therefore, we suggest that other parameters control the gamma-ray activity. As a result, gamma-ray activity is a poor proxy for velocity. In contrast, measurements of gamma-ray activity and velocity for samples from the Vercors (France), show a high correlation (unpubl. data; Stafleu et al., in press). Discrete measurements of velocity and density as input produce some correlations, but most are obscured by the absence of data points. In addition, their overall velocity is higher than the sonic log velocity, which may have been caused by factors such as poor sample coverage and depth matching from low recovery and velocity dispersion (a.o., Bourbié et al., 1987; Paillet and Cheng, 1991).

\section{SUMMARY AND CONCLUSIONS}

The construction of synthetic seismograms from sonic velocity and density and their comparison with the seismic reflection profile at Site 866 has several implications for the study of seismic reflection profiles over Cretaceous Mid-Pacific guyots.

First, high-amplitude reflections in the synthetic seismograms are caused by lithologic boundaries related to changes in sea level or oceanographic events, to changes in diagenetic signature (dolomitization), or to interference processes.

Second, poor correlation between the synthetic seismogram and reflection seismic profile may be related to quality of recording, to rapid lateral changes in lithology or diagenetic overprinting, or to changing interference patterns. The precise cause remains unclear, but it is difficult to identify reflections as evidence for changes in sea level or oceanographic events that can be correlated to other guyots.

Third, as the impedance contrasts between limestone and basalt in these guyots is smaller, or equal to, the impedance contrasts within the limestone succession, it is difficult to identify a basement reflection.

Fourth, synthetic seismograms calculated from sonic velocity, neutron density, neutron porosity, and resistivity produce similar results. The gamma-ray data are poorly correlated to impedance, as clay content is not the primary source of gamma-ray activity; density shows a good correlation, as Gardner's equation works well for pure limestone, and Wyllie's equation underestimates velocity. Discrete measurements yield velocities that are about $10 \%$ to $15 \%$ higher than sonic velocity. The resulting synthetic trace shows most major reflections, but lacks resolution because of poor sample coverage. 


\section{ACKNOWLEDGMENTS}

We thank Captain Ed Oonk and the crew of the JOIDES Resolution, along with the ODP technical staff, for their support and cooperation during Leg 143. Marc Reinders is acknowledged for his assistance with the laboratory analyses. We thank Will Sager, Jerry Winterer, and two anonymous reviewers for their helpful comments. Funding to the first author was provided by the Dutch National Science Foundation Grant No. 751.356.028 to Wolfgang Schlager. This study is part of a dissertation by J. Stafleu at the Vrije Universiteit, supervised by Wolfgang Schlager. Financial support to J. Stafleu was provided by the Vrije Universiteit. Additional support came from the University's Industrial Associates Program in Sedimentology.

\section{REFERENCES}

Adcock, S., 1993. In search of the well tie: what if we don't have a sonic log? The Leading Edge, 1161-1164.

Biddle, K.T., Schlager, W., Rudolph, K.W., and Bush, T.L., 1992. Seismic model of a progradational carbonate platform, Picco di Vallandro, the Dolomites, northern Italy. AAPG Bull., 76:14-30.

Bourbié, T., Coussy, O., and Zinszner, B., 1987. Acoustics of Porous Media: Paris (Ed. Technip.)

Campbell, A.E., and Stafleu, J., 1992. Seismic modeling of an Early Jurassic, drowned carbonate platform: Djebel Bou Dahar, High Atlas, Morocco. AAPG Bull., 76:1760-1777.

Carmichael, R.S., 1989. Practical Handbook of Physical Properties of Rocks and Minerals: Boca Raton, FL (CRC Press).

Christensen, N.I., and Szymanski, D.L., 1991. Seismic properties and the origin of reflectivity from a classic Paleozoic sedimentary sequence, valley and Ridge province, southern Appalachians. Geol. Soc. Am. Bull., 103:277-289.

Folger, D.W., 1986. Sea-floor observations and subbottom seismic characteristics of OAK and KOA craters, Enewetak Atoll, Marshall Islands: Introduction. U.S. Geol. Surv. Bull., 1678.

Fulthorpe, C.S., Schlanger, S.O., and Jarrard, R.D., 1989. In situ acoustic properties of pelagic carbonate sediments on the Ontong Java Plateau. $J$. Geophys. Res., 94:4025-4032.

Gardner, G.H.F., Gardner, L.W., and Gregory, A.R., 1974. Formation velocity and density: the diagnostic basics for stratigraphic traps. Geophysics. 39:770-780.

Matthews, J.L., Heezen, B.C., Catalano, R., Coogan, A., Tharp, M., Natland, J., and Rawson, M., 1974. Cretaceous drowning of reefs on Mid-Pacific and Japanese guyots. Science, 184:462-464.

Mayer, L.A., Shipley, T.H., and Winterer, E.L., 1986. Equatorial Pacific seismic reflectors as indicators of global oceanographic events. Science, 233:761-764.

McNutt, M.K., and Fischer, K.M., 1987. The South Pacific superswell. In Keating, B.H., Fryer, P., Batiza, R., and Boehlert, G.W. (Eds.), Seamounts,
Islands, and Atolls. Am. Geophys. Union, Geophys. Monogr. Ser., 43:2534.

Menard, H.W., 1984. Darwin reprise. J. Geophys. Res., 89:9960-9968.

Nafe, H.E., and Drake, C.L., 1963. Physical properties of marine sediments. In Hill, M.N. (Ed.), The Sea (Vol. 3): New York (Wiley-Interscience), 794-815.

ODP Leg 143 Shipboard Scientific Party, 1993. Examining guyots in the Mid-Pacific mountains. Eos, 74:201-206.

Paillet, F.L., and Cheng, C.H., 1991. Acoustic Waves in Boreholes: Boca Raton, FL (CRC Press).

Rudolph, K.W., Schlager, W., and Biddle, K.T., 1989. Seismic models of a carbonate foreslope-to-basin transition, Picco di Vallandro, Dolomite Alps, northern Italy. Geology, 17:453-456.

Sager, W.W., Winterer, E.L., Firth, J.V., et al., 1993. Proc. ODP, Init. Repts., 143: College Station, TX (Ocean Drilling Program).

Sheriff, R.E., and Geldart, L.P, 1983. Exploration Seismology (Vol. 2): Data Processing and Interpretation: Cambridge (Cambridge Univ. Press).

Shipley, T.H., Mayer, L.A., and Winterer, E.L., 1989. Seismic reflections and sedimentation in the pelagic Equatorial Pacific. In Bally, A.W. (Ed.), Atlas of Seismic Stratigraphy (Vol. 3). AAPG Stud. Geol., 27:224-231.

Shipley, T.H., Winterer, E.L., and Lonsdale, P., 1983. Seismic-stratigraphic analysis in the pelagic environment: the Central Hess Rise, Northwest Pacific. Mar. Geol., 51:47-62.

Stafleu, J., Everts, A.J.W., and Kenter, J.A.M., in press. Seismic models of a prograding carbonate platform: Vercors, SE France. Mar. Pet. Geol.

Wardlaw, B.R., 1989. Comment on "Strontium-isotope stratigraphy on Enewetak Atoll." Geology, 17:190-191.

Winterer, E.L., 1973. Sedimentary facies and plate tectonics of the equatorial Pacific. AAPG Bull., 57:265-282.

1991. Pelagic sediments, seismic reflectors, and changes in sea level. In Muller, D., Weissert, H., and McKenzie J. (Eds.), Controversies in Modern Geology: London (Academic Press), 211-230.

Winterer, E.L., and Metzler, C.V., 1984. Origin and subsidence of guyots in Mid-Pacific Mountains. J. Geophys. Res., 89:9969-9979.

Wyllie, M.R.J., Gregory, A.R., and Gardner, G.H.F., 1958. An experimental investigation of factors affecting elastic wave velocities in porous media. Geophysics, 23:400.

Abbreviations for names of organizations and publications in ODP reference lists follow the style given in Chemical Abstracts Service Source Index (published by American Chemical Society).

Date of initial receipt: 29 November 1993

Date of acceptance: 13 June 1994

Ms 143SR-248 